PACS: $87.14 . \mathrm{Cc}$, 87.16.Dg

\title{
EFFECT OF AMYLOID FIBRILS ON ELECTROKINETIC PROPERTIES OF LIPID VESICLES
}

\author{
U. Tarabara ${ }^{1}$, K. Vus ${ }^{1}$, S. Girnyk ${ }^{1}$, N. Kamneva ${ }^{2}$, O. Lavryk ${ }^{1}$, \\ M. Mikhailyuta ${ }^{1}$, V. Trusova ${ }^{1}$, G. Gorbenko ${ }^{1}$ \\ ${ }^{1}$ Department of Nuclear and Medical Physics, V.N. Karazin Kharkiv National University \\ ${ }^{2}$ Department of Physical Chemistry, V.N. Karazin Kharkiv National University \\ 4 Svobody Sq., Kharkiv, 61022, Ukraine \\ e-mail: uliana.tarabara@gmail.com \\ Received April 1, 2017
}

The influence of the lysozyme and serum albumin in their native and amyloid forms on the electrokinetic behavior of the negatively charged uni- and multilamellar liposomes from the zwitterionic lipid phosphatidylcholine and anionic lipid cardiolipin has been investigated using the microelectrophoresis technique. The zeta - potential, the surface electrostatic potential and surface charge density of the lipid vesicles have been determined upon varying the lipid-to-protein molar ratio. The complex dependencies of the electrophoretic mobility on the protein concentration and reversal of the surface charge observed for the multilamellar vesicles have been explained by the multilayer protein adsorption on the liposomal surface. It has been found that the native and fibrillar proteins differ in their ability to modify the charge state of the model membranes.

KEYWORDS: electrophoretic mobility, lipid vesicles, lysozyme, serum albumin, amyloid fibrils

\section{ВЛИЯНИЕ АМИЛОИДНЫХ ФИБРИЛЛ НА ЭЛЕКТРОКИНЕТИЧЕСКИЕ СВОЙСТВА ЛИПИДНЫХ ВЕЗИКУЛ}

У. Тарабара ${ }^{1}$, Е. Вус ${ }^{1}$, С. Гирнык ${ }^{1}$, Н. Камнева ${ }^{2}$, О. Лаврик ${ }^{1}$,

М. Михайлюта ${ }^{1}$, В. Трусова ${ }^{1}$, Г. Горбенко ${ }^{1}$

${ }^{l}$ Кафедра ядерной и медицинской физики, Харьковский национальный университет имени В.Н. Каразина

${ }^{2}$ Кафедра физической химии, Харьковский национальньй университет имени В.Н. Каразина

Харьковский национальный университет им. В.Н. Каразина

пл. Свободьи 4, Харьков, 61022, Украина

Методом микроэлектрофореза исследовано влияние нативной и амилодной форм лизоцима и сывороточного альбумина на электрокинетическое поведение моно- и мультиламеллярных липосом из цвиттерионного липида фосфатидилхолина и анионного липида кардиолипина. При варьировании молярного соотношения липид:белок были определены дзета потенциал, поверхностный электростатический потенциал и поверхностная плотность заряда липидных везикул. Сложная зависимость электрофоретической подвижности от концентрации белка и изменение знака поверхностного заряда, выявленные для мультиламеллярных везикул, были объяснены мультислойной адсорбцией белков на поверхности липосом. Обнаружено, что нативная и фибриллярная формы белков различаются по их способности модифицировать зарядовое состояние модельных мембран.

КЛЮЧЕВЫЕ СЛОВА: электрофоретическая подвижность, липидные везикулы, лизоцим, сывороточный альбумин, амилоидные фибриллы

\section{ВПЛИВ АМІЛОЇДНИХ ФІБРИЛ НА ЕЛЕКТРОКІНЕТИЧНІ ВЛАСТИВОСТІ ЛІПІДНИХ ВЕЗИКУЛ У. Тарабара ${ }^{1}$, К. Вус ${ }^{1}$, С. Гірник ${ }^{1}$, Н. Камнєва ${ }^{2}$, О. Лаврик ${ }^{1}$, М. Михайлюта ${ }^{1}$, В. Трусова $^{1}$, Г. Горбенко ${ }^{1}$ \\ ${ }^{l}$ Кафедра ядерної та медичної фізики, Харківський національний університет імені В.Н. Каразіна \\ ${ }^{2}$ Кафедра фізичної хімії, Харківський національний університет імені В.Н. Каразіна пл. Свободи 4, Харків, 61022, Украӥна}

Методом мікроелектрофорезу досліджено вплив нативної та амілоїдної форм лізоциму та сироваткового альбуміну на електрокінетичну поведінку моно- и мультиламелярних ліпосом із цвіттеріонного ліпіду фосфатидилхоліну та аніонного ліпіду кардіоліпіну. При варіюванні молярного співвідношення ліпід:білок було визначено дзета - потенціал, поверхневий електростатичний потенціал та поверхневу густину заряду ліпідних везикул. Складна залежність електрофоретичної рухливості від концентрації білка та зміна знаку поверхневого заряду, виявлені для мультиламелярних везикул, було пояснено мультишаровою адсорбцією білків на поверхні ліпосом. Встановлено, що нативна та фібрилярна форми білків відрізняються за їх здатністю модифікувати зарядовий стан модельних мембран.

КЛЮЧОВІ СЛОВА: електрофоретична рухливість, ліпідні везикули, лізоцим, сироватковий альбумін, амілоїдні фібрили

Electrostatic phenomena are known to play an essential role in determining the structural and functional properties of biological systems [1,2]. In particular, electrostatics controls a wide variety of processes occurring in cellular membranes, among which are non-specific and specific protein-lipid interactions, protein folding, translocation and orientation in the lipid bilayer [3-5], enzyme functioning, ion binding and transport, structural and phase transitions in the lipid phase [1], recognition events [6,7], pharmacological effects [8], etc. Biological membranes consist of hundreds of different molecular species including lipids, proteins and carbohydrates bearing numerous ionized groups which account for the net negative charge of the membrane surface [1]. An essential part of such groups belong to anionic lipids such as phosphatidylglycerol, cardiolipin, phosphatidylserine, phosphatidic acid and phosphatidylinositol, whose (C) Tarabara U., Vus K., Girnyk S., Kamneva N., Lavryk O., Mikhailyuta M., Trusova V., Gorbenko G., 2017 
fraction is typically less than $30 \%$ of the total membrane lipids [9]. These lipids are involved in specific interactions with protein sequences containing positively charged side amino acids, such as arginine, lysine or histidine. The interactions between oppositely charged groups of proteins and lipids is a fundamental biological phenomenon implicated in a range of important membrane-related processes, particularly, in selective binding of cationic cellpenetrating, antimicrobial and viral peptides, toxins or ion channels [10-12] and protein aggregation associated with amyloid disorders including neurological diseases, type II diabetes, spongiform encephalophaties, rheumatoid arthritis, etc. [13-17]. These pathologies are provoked by misfolding of specific proteins and their self-assembly into highly ordered aggregates, amyloid fibrils [18,19]. Amyloid fibrils are self-assembled protein nanostructures distinguished by the core supramolecular $\beta$-sheets propagating along the main axis of the fibril with $\beta$-strands running perpendicularly to this axis.

Accumulating evidence indicates that cell membranes represent a direct target for the toxic pre-fibrillar and fibrillar aggregates of misfolded proteins which cause membrane damage and subsequent cell death [20]. According to the current concepts, the cytotoxic potential of aggregated proteins may originate from the loss of membrane integrity [21], appearance of non-specific ion channels [22], uptake of lipids into the growing fiber [23], modifications of the intracellular redox status and free calcium level [24], and impaired functional activity of membrane proteins [20]. Obviously, an initial step of membrane damage involves the binding of protein aggregates with the surface of lipid bilayer. In many cases such binding is driven by electrostatic protein-lipid interactions and may lead to significant change of the membrane surface charge, thereby influencing a number of electrostatically-controlled membrane processes. In view of a high structural and compositional heterogeneity of biological membranes, a common approach to investigating the above processes is based on the use of the model systems containing isolated proteins in a certain conformational and aggregation state and lipid vesicles (liposomes) whose lipid components and physicochemical parameters can be varied in a wide range.

In the present study we used the model protein-lipid systems containing as a protein component lysozyme or serum albumin in the native or fibrillar states and multilamellar lipid vesicles composed of zwitterionic lipid phosphatidylcholine and anionic lipid cardiolipin. Lysozyme is a well-characterized multifunctional cationic protein possessing bactericidal, antitumor and immunomodulatory properties. The mutants of human lysozyme (I56T, F57I, W64R, D67H) undergo pathological fibrillization implicated in etiology of familial nonneuropathic systemic amyloidosis, a disease affecting kidney, liver and spleen [25]. Serum albumin is an anionic protein that performs a number of physiological functions associated with the binding, transport and distribution of biologically active compounds. Being prone to amyloid transformation under denaturing conditions, this protein is extensively employed in the model studies of the protein aggregation and fibrillization [26,27]. Our goal was to obtain a direct evidence for the binding of amyloid fibrils of lysozyme and albumin to lipid vesicles and to compare the effects of the native and fibrillar proteins on the surface charge of lipid bilayer through measuring the electrophoretic mobility of the uni- and multilamellar lipid vesicles.

\section{EXPERIMENTAL SECTION \\ Materials}

Egg yolk phosphatidylcholine (PC) and beef heart cardiolipin (CL) were purchased from Avanti Polar Lipids (Alabaster, AL). Hen egg white lysozyme and bovine serum albumin were from Sigma (St. Louis, MO, USA). All other chemicals were of analytical grade and used without further purification.

\section{Preparation of lipid vesicles}

Multilamellar lipid vesicles (MLV) were prepared from PC mixture with $20 \mathrm{~mol} \%$ of CL. Appropriate amounts of lipid stock solutions were mixed in ethanol and evaporated to dryness under a vacuum. The obtained thin lipid films were hydrated with $1.2 \mathrm{ml}$ of $5 \mathrm{mM}$ sodium phosphate buffer ( $\mathrm{pH} \mathrm{7.4)}$ at room temperature. The acquired lipid vesicles were visualized using the optical and fluorescence microscopy techniques (Fig. 1). To obtain the fluorescence microscopy images, the lipid vesicles were stained with acridine orange.

To prepare the large unilamellar liposomes (LUV) with the 100-nm diameter, the suspension of MLV was subjected to 15 passes through a 100-nm pore size polycarbonate filter (Millipore, Bedford, USA). Hereafter, the MLV and LUV employed in the electrophoretic measurements are denoted as $\mathrm{MLV}_{\mathrm{CL} 20}$ and $\mathrm{LUV}_{\mathrm{CL} 20}$, respectively.

\section{Measurements of electrophoretic mobility and zeta-potential}

The electrophoretic mobility of MLV suspended in $5 \mathrm{mM}$ sodium phosphate buffer ( $\mathrm{pH}$ 7.4) was measured in a laterally oriented electrophoretic chamber. The current through the cell was determined with an ammeter. Liposome migration in the stationary Smoluchowski layer was observed with a BIOLAM microscope at $20{ }^{\circ} \mathrm{C}$. The rate of migration was determined from the time required for liposomes to pass a fixed distance $(79.17 \mu \mathrm{m})$ upon the change of the voltage polarity. The electrophoretic mobility $(u)$ was calculated as $u=l / t E$, where $l$ is the distance covered by a vesicle in time $t, E$ is the electric field strength. The $u$ value was averaged over 20-40 measurements. Statistical analysis of the experimental data was performed in Mathcad 11. The Helmholtz-Smoluchowski equation was used to calculate the electrokinetic potential $\zeta=u \eta / \varepsilon_{r} \varepsilon_{0}$, here $\eta$ denotes the viscosity of the medium, $\varepsilon_{r}$ and $\varepsilon_{0}$ are the 
dielectric constants of the aqueous phase and vacuum, respectively. The zeta-potentials of the unilamellar lipid vesicles were determined using Zetasizer Nano ZS Malvern Instruments apparatus, equipped by the temperature controller. Specifically, $0.8 \mathrm{ml}$ of the samples were injected in Zeta dip cell, and the measurement was performed at $20{ }^{\circ} \mathrm{C}$. The zeta-potential values were determined as the average of 3 repeats.

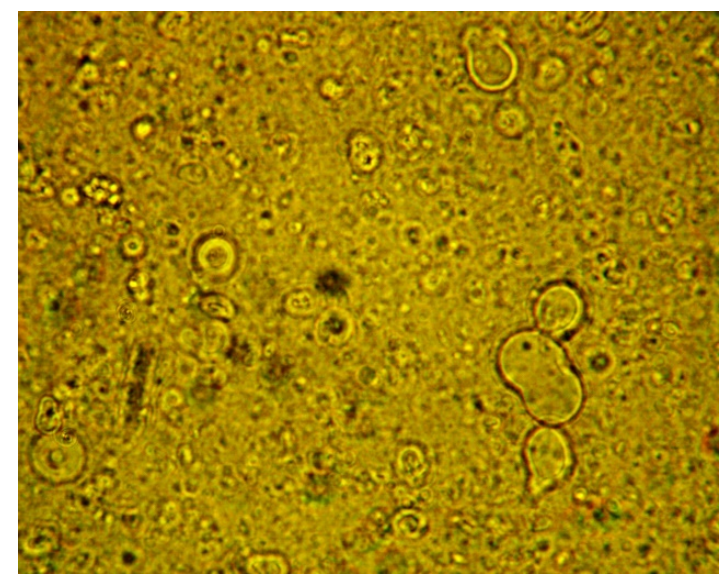

a

Fig. 1. The images of multilamellar lipid vesicles

a - obtained using optical microscopy, b - obtained using fluorescence microscopy

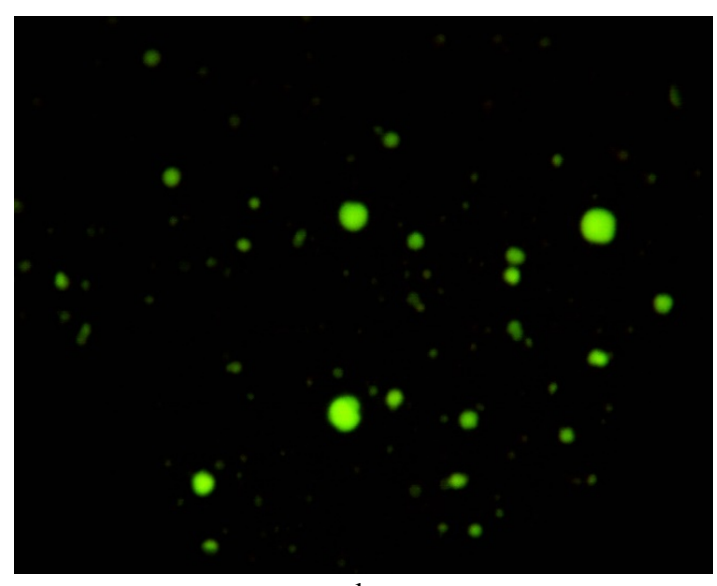

b

\section{Preparation of amyloid fibrils}

Amyloid fibrils of lysozyme and albumin were produced by dissolving the protein $(10 \mathrm{mg} / \mathrm{ml})$ in $10 \mathrm{mM}$ glycine buffer, $\mathrm{pH}$ 2, and incubating for 2 weeks at $60^{\circ} \mathrm{C}$. Fibril formation was assessed by transmission electron microscopy (Fig. 2). A 5- $\mu 1$ drop of concentrated protein solution was applied to a carbon-coated Formvar grid, and blotted after 60 sec. A $5-\mu 1$ drop of $2 \%$ uranyl acetate solution was placed on the grid, blotted after $30 \mathrm{sec}$, washed by deionized water, air dried and examined using a Tecnai 12 Bio-Twin transmission electron microscope operating at an accelerating voltage of $80 \mathrm{kV}$.

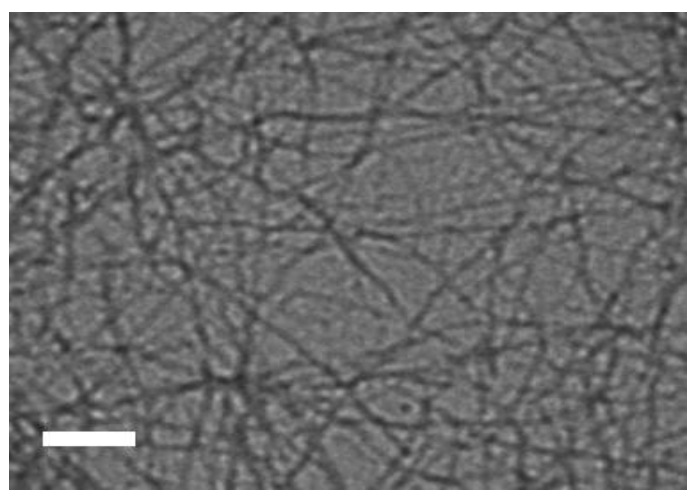

a

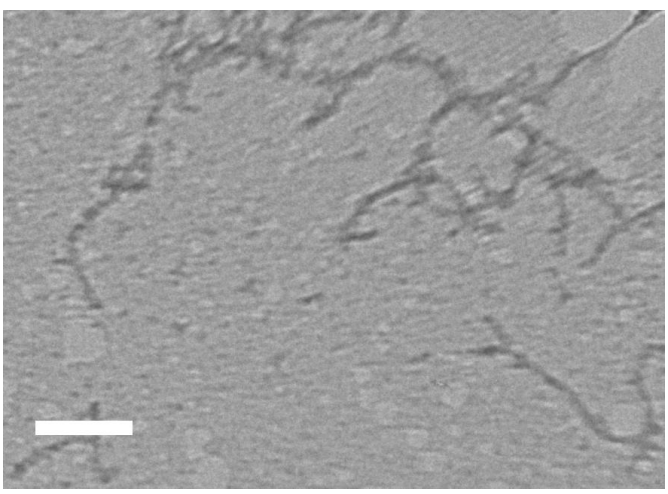

b

Fig. 2. TEM images fibrils formed at $\mathrm{pH} 2.0,60^{\circ} \mathrm{C}$ a - hen egg white lysozyme, b - bovine serum albumin. Scale bars are $200 \mathrm{~nm}$ (a) and $50 \mathrm{~nm}$ (b)

\section{RESULTS AND DISCUSSION}

Liposomes are formed due to self-assembly of amphiphilic lipid molecules in an aqueous phase into spherical or quasispherical vesicles consisting of an aqueous central cavity and a single bilayer shell (unilamellar vesicles) or multiple bilayer shells (multilamellar vesicles). The surface potential of lipid vesicles $\left(\psi_{s}\right)$ is created by the charges of the lipid headgroups, adsorbed ions and counterions residing at the lipid-water interface [1,2]. The surface potential is determined by the content and type of the charged lipids and the concentration of protons and ions in the adjacent layer. The simplest description of the membrane surface potential is provided by the Gouy-Chapman-Stern double layer theory which is valid when the charge is uniformly distributed over a planar surface [28]. In terms of this theory the electrostatic free energy of a membrane with the area $S_{m}=S_{L} L_{\text {out }}$ is given by [29]:

$$
F_{e l}^{s}=\frac{2 k_{B} T S_{m}}{e}\left(\sigma \sinh ^{-1}\left(\frac{\sigma}{a}\right)-\sqrt{a^{2}+\sigma^{2}}+a\right)
$$


where $\sigma$ is the surface charge density, $a=\sqrt{2 \pi^{-1} \varepsilon c N_{A} k_{B} T} ; N_{A}$ is Avogadro's number, $\varepsilon$ is the dielectric constant, $c$ is the molar concentration of monovalent ions, $T$ is the temperature, $k_{B}$ is the Boltzmann's constant, $L_{\text {out }}$ is the concentration of accessible lipids which for unilamellar liposomes is related to the total lipid concentration $(L)$ as $L_{\text {out }}=0.5 L ; S_{L}$ is the mean area per lipid molecule:

$$
S_{L}=f_{P C} S_{P C}+f_{A} S_{A},
$$

here $f_{P C}, f_{A}$ are the mole fractions of $\mathrm{PC}$ and the anionic phospholipid; $S_{P C}$ is the mean area per PC molecule $(0.65$ $\left.\mathrm{nm}^{2}\right) ; S_{A}$ is the mean area per molecule of anionic phospholipid taken as and $1.2 \mathrm{~nm}^{2}$ for CL. The surface charge density $(\sigma)$ is determined by the mole fraction of anionic phospholipid $\left(f_{A}\right)$ and the degree of its ionization $(\alpha)$ :

$$
\sigma=\frac{-e \alpha f_{A} L_{o u t}}{S_{m}},
$$

where $e$ is the elementary charge, $\alpha=1$ for phosphatidylglycerol or phosphatidylserine, and $\alpha=2$ for cardiolipin [30]. The electrostatic surface potential of a membrane $\left(\psi_{s}\right)$ is related to the surface charge density as:

$$
\psi_{s}=\frac{2 k_{B} T}{e} \sinh ^{-1}\left(\frac{\sigma}{a}\right)
$$

The so-called zeta potential $(\zeta$ ) derived from the measurements of electrophoretic mobility of the lipid vesicles or cells can be regarded as a component of the surface membrane potential $\psi_{s} . \zeta$ - potential is a potential at the plane of shear separating the compact and diffuse parts of the double layer. The plane of share may reside up to 2-3 water diameter away from the surface. In the compact part, adjacent to the surface, the ions are immobilized and move together with the vesicle or cell, while in the diffuse part the ions are mobile and distribute according to the laws of statistical mechanics. The compact part of the double layer is determined by the inner and outer Helmholtz planes. The inner plane, residing at the distance $\sim 0.1-0.2 \mathrm{~nm}$ from the membrane, represents the plane of closest approach of nonhydrated ions to the surface. The outer Helmholtz plane is located at $\sim 0.6 \mathrm{~nm}$ from the surface and characterizes the closest approach of the hydrated ions. The share plane lies close to the outer Helmholtz plane [31-33]. The calculation of the average electrophoretic mobility of colloidal particles requires the solution of a set of partial differential equations (electrokinetic equations) for the electrical potential, ion densities and fluid velocities in the suspending electrolyte. The electromigration of lipid vesicles is an especially complex process that cannot be described by the classical electrokinetic theory, postulating a direct relation between the electrophoretic mobility $(u)$ and the particle charge $(q)$ :

$$
u=q / 6 \pi \eta R
$$

here $R$ is the particle radius. However, for large particles, such as colloids or liposomes, this equation is not valid and special models have been developed for these systems [34-35]. In contrast to the classical electrokinetic theory, these models allow for the effects of relaxation and retardation, both of which reduce the rate of electrophoretic migration of large particles. Relaxation arises from the distortion of the ionic atmosphere during the particle movement, while retardation is brought about by the enhancement of hydrodynamic drag when counterions move in the opposite to particle direction in the applied field. Within the framework of the electrokinetic models proposed for the large colloidal particles the extent of relaxation effects is treated as being dependent on the inverse thickness of the electric double layer (or inverse Debye length, $\left.\kappa=\left(2 e^{2} N_{A} c / k_{B} T \varepsilon_{0} \varepsilon_{r}\right)^{1 / 2}\right)$, the particle radius $R$ and $\zeta$ - potential. One of the existing colloidal theories applicable to describing the electromigration of liposomes has been suggested by O'Brien [35,36]. According to this theory, the electrophoretic mobility of spherical particles with $R>>\kappa$ is given by:

$$
\begin{gathered}
u=\frac{3 e \zeta}{2 k_{B} T}+\frac{3 M \lambda}{2(1+\lambda M)}\left(1-\exp \left(\frac{-e\left|z_{i} \zeta\right|}{2 k_{B} T}\right)\right)\left(\gamma-\frac{e \zeta}{k_{B} T}\right) . \\
\lambda=\exp \left(\frac{-e\left|z_{i} \zeta\right|}{2 k_{B} T}\right) / \alpha \kappa R ; \quad \alpha=\left|z_{i}\right|\left(\frac{n_{i}^{\infty}}{2}\right)^{1 / 2} ; \quad M=1+\frac{3 \sum_{j} n_{j}^{\infty} m_{j}}{z_{i}^{2} \sum_{k} n_{k}^{\infty}} ; \quad m_{j}=\frac{\varepsilon\left(k_{B} T\right)^{2}}{6 \pi \eta e^{2} D_{j}},
\end{gathered}
$$

where summation is performed over ionic species for which $z_{k, j}=z_{i}, m_{j}$ is the nondimensional ionic drag coefficient, $D_{j}$ is the ion diffusivity, $\gamma=2 \ln 2 / z$ for a symmetric two species electrolyte, $z$ is the magnitude of ion valency, index $i$ refers to the counterion with the highest valency, $n_{i}^{\infty}$ is the equilibrium ion density beyond the 
double layer, if there are more than one counterion species, $n_{i}^{\infty}$ should be replaced by a sum over the bulk densities of these ions. Despite being more adequate in interpreting the electrokinetic behavior of liposomes, Eq. (6) is valid for the rigid and nondeformable spherical particles. However, lipid vesicles possess intrinsic deformability, so that they can undergo a variety of shape deformations. This property can to some extent be taken into account by considering the lipid vesicles as prolate spheroids whose electrophoretic mobility is expressed by the equation [36]:

$$
u=\frac{\varepsilon \zeta}{\eta}+\frac{\varepsilon k_{B} T}{3 \eta e}\left(\frac{e \zeta}{k_{B} T}-\gamma\right)\left[g^{0}(\beta)+2 g^{1}(\beta)\right],
$$

where $g^{0}(\beta)$ pertains to the velocity components of ellipsoids whose major axis is aligned with the applied field, while $g^{1}(\beta)$ characterizes the ellipsoids with major axis transverse to the field. At last, most electrokinetic theories consider the particles with a uniform charge distribution whose ionic atmosphere is only slightly distorted by the applied field, ignoring the possibility of field-induced charge migration over the particle surface which may occur in the fluid lipid bilayers [37,38]. It has been demonstrated that charge migration may lead to polarization and elongation of lipid vesicles along the direction of the applied field [39,40]. Thus, the factors, such as relaxation, retardation, deformability and field-induced polarization must be taken into account while interpreting the electrokinetic behavior of liposomes.

The alterations of the electrophoretic mobility of $\mathrm{MLV}_{\mathrm{CL} 20}$ upon the adsorption of the native or fibrillar lysozyme and serum albumin are shown in Fig. 3. As expected, in the absence of protein the $u$ value has the negative sign. However, at varying the protein concentration $(P)$ electrophoretic mobility was found to display a complex behavior involving a complete neutralization of liposome charge or its reversal.
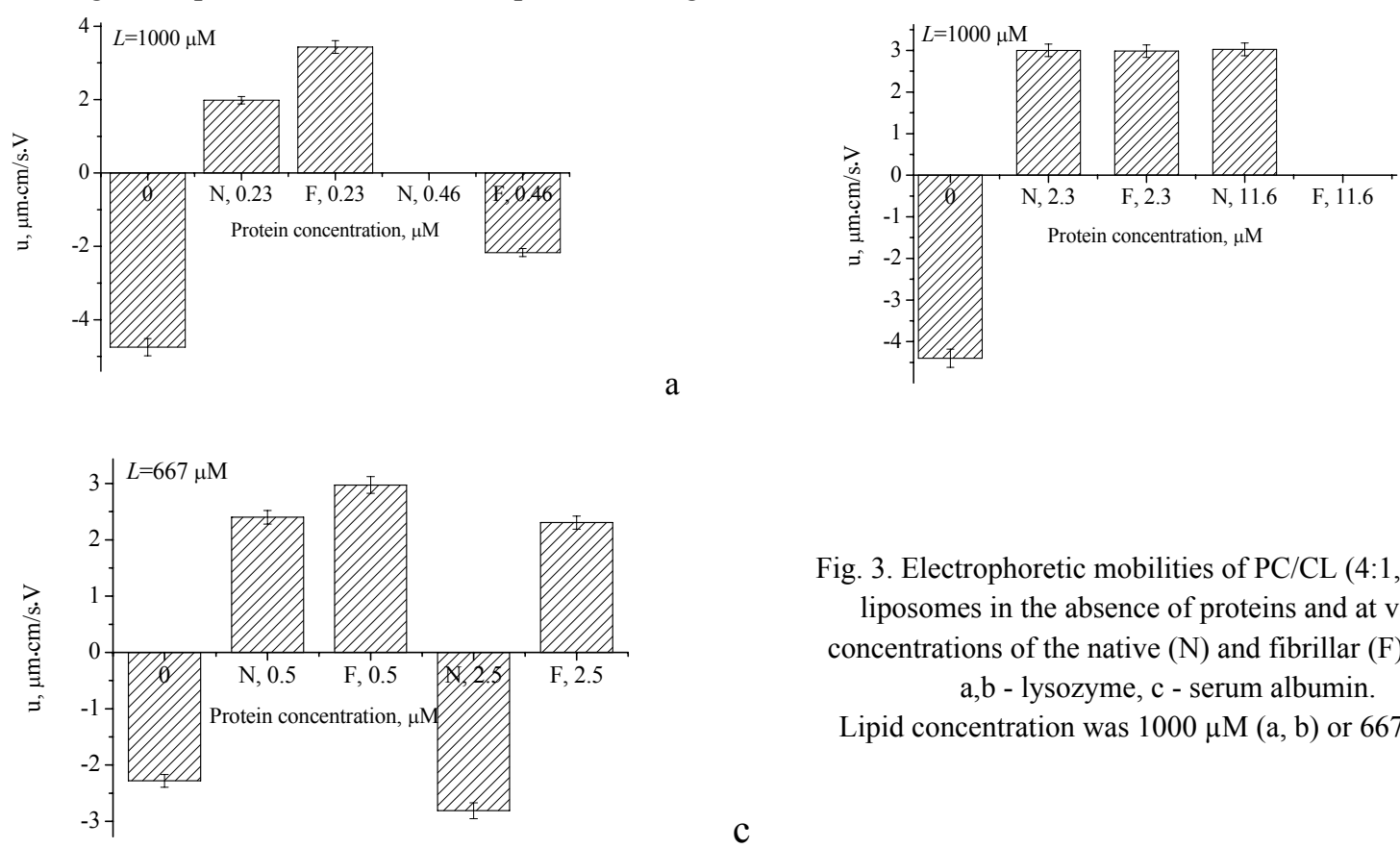

Fig. 3. Electrophoretic mobilities of PC/CL (4:1, mol:mol) liposomes in the absence of proteins and at varying concentrations of the native $(\mathrm{N})$ and fibrillar $(\mathrm{F})$ proteins a,b - lysozyme, c - serum albumin.

Lipid concentration was $1000 \mu \mathrm{M}(\mathrm{a}, \mathrm{b})$ or $667 \mu \mathrm{M}$ (c)

c

It appeared that even at the minimum concentration of the native lysozyme $(0.23 \mu \mathrm{M})$ the surface charge of liposomes changes its sign from negative to positive, i.e. the protein covers all accessible surface area of MLV $\mathrm{CL20}_{\text {. }}$ Given that the radius of lysozyme monomers is $\sim 1.9 \mathrm{~nm}$, the cross-section of structurally unperturbed protein is $\sim 11.3$ $\mathrm{nm}^{2}$, i.e. one protein molecules is capable of covering at least 15 lipid molecules (with the mean area per lipid molecule $S_{L} \sim 0.76 \mathrm{~nm}^{2}$ ). Assuming the monolayer adsorption of lysozyme onto lipid vesicles, one obtains that upon complete protein binding the accessible surface area at $L=1000 \mu \mathrm{M}$ equals $\sim 2.6 \mathrm{~nm}^{2}$, i.e. only $3.4 \mu \mathrm{M}$ of lipids are capable of associating with protein. According to the optical and fluorescence microscopy data, the diameter of $M_{L} V_{C L 20}$ falls in the range 5-40 $\mu \mathrm{m}$. Taking into account the mean area per lipid, it follows that the outer monolayer of one $40 \mu \mathrm{m}-\mathrm{MLV}$ contains $\sim 132$ lipid molecules, while the aqueous cavity of such vesicle may incorporate many vesicles of the smaller size. As a consequence, the amount of lipids accessible for the protein binding significantly decreases, and the actual ratio $L_{\text {out }} / P \sim 15$ will be much less than the maximum possible value of this parameter corresponding to the case of lipid self-assembly into unilamellar vesicles. Thus, increase of the protein concentration creates the conditions for multilayer adsorption since $L_{\text {out }} / P$ will decrease. The factors, such as the alterations in the protein tertiary structure, asymmetry of the distribution of positively and negatively charged groups on the protein surface, the extent of exposure 
of hydrophobic patches, the orientation of the protein molecule relative to lipid-water interface, may lead to the alternative changes of the sign of vesicle charge depending of the number of the adsorbed layers. Indeed, as can be seen in Fig. 3 and Table 1, as the concentration of the native lysozyme increases from $0.23 \mu \mathrm{M}$ to $0.46 \mu \mathrm{M}$, the liposome charge becomes neutral, while at further increase of $P$ value till $2.3 \mu \mathrm{M}$ and $11.6 \mu \mathrm{M}$ the vesicles again acquire a positive charge. A somewhat different situation was observed for fibrillar lysozyme - with increase of the protein concentration from $0.23 \mu \mathrm{M}$ to $0.46 \mu \mathrm{M}$ the charge of liposomes changes its sign from positive to negative, then, at $P=2.3 \mu \mathrm{M}$ the charge becomes positive, and at $P=11.6 \mu \mathrm{M}$ the vesicle charge was completely neutralized.

Table 1.

Electrokinetic properties of the multilamellar PC/CL (4:1, mol:mol) vesicles in the presence of the native or fibrillar lysozyme and serum albumin

\begin{tabular}{|c|c|c|c|c|c|c|}
\hline Protein & $\begin{array}{c}\text { Lipid } \\
\text { concentration, } \\
\mu \mathrm{M}\end{array}$ & $\begin{array}{c}\text { Protein } \\
\text { concentration, } \\
\mu \mathrm{M}\end{array}$ & $u, \mu \mathrm{m} \cdot \mathrm{cm} / \mathrm{s} \cdot \mathrm{V}$ & $\zeta, \mathrm{mV}$ & $\psi_{s}, \mathrm{mV}$ & $\sigma, \mathrm{C} / \mathrm{m}^{2}$ \\
\hline \multirow{5}{*}{$\begin{array}{l}\text { Fibrillar } \\
\text { lysozyme }\end{array}$} & 1000 & 0 & $-4.40 \pm 0.48$ & -62.3 & -66.0 & $-1.4 \cdot 10^{-2}$ \\
\hline & 1000 & 0.23 & $3.43 \pm 0.29$ & 48.5 & 46.0 & $8.6 \cdot 10^{-3}$ \\
\hline & 1000 & 0.46 & $-2.17 \pm 0.16$ & -30.7 & -32.3 & $-5.6 \cdot 10^{-3}$ \\
\hline & 1000 & 2.3 & $2.98 \pm 0.20$ & 42.2 & 44.5 & $8.2 \cdot 10^{-3}$ \\
\hline & 1000 & 11.6 & 0 & 0 & 0 & 0 \\
\hline \multirow{4}{*}{$\begin{array}{l}\text { Native } \\
\text { lysozyme }\end{array}$} & 1000 & 0.23 & $1.98 \pm 0.21$ & 28.0 & 29.4 & $5.1 \cdot 10^{-3}$ \\
\hline & 1000 & 0.46 & 0 & 0 & 0 & 0 \\
\hline & 1000 & 2.3 & $3.00 \pm 0.27$ & 42.5 & 44.8 & $8.3 \cdot 10^{-3}$ \\
\hline & 1000 & 11.6 & $3.03 \pm 0.33$ & 42.9 & 45.3 & $8.4 \cdot 10^{-3}$ \\
\hline \multirow{3}{*}{$\begin{array}{l}\text { Fibrillar } \\
\text { serum } \\
\text { albumin }\end{array}$} & 667 & 0 & $-2.28 \pm 0.21$ & -32.3 & -30.0 & $-5.2 \cdot 10^{-3}$ \\
\hline & 667 & 0.5 & $2.97 \pm 0.28$ & 42.0 & 43.0 & $7.9 \cdot 10^{-3}$ \\
\hline & 667 & 2.5 & $2.31 \pm 0.19$ & 32.7 & 34.4 & $6.0 \cdot 10^{-3}$ \\
\hline \multirow{2}{*}{$\begin{array}{l}\text { Native } \\
\text { serum } \\
\text { albumin }\end{array}$} & 667 & 0.5 & $2.40 \pm 0.28$ & 34.0 & 35.8 & $6.3 \cdot 10^{-3}$ \\
\hline & 667 & 2.5 & $-2.81 \pm 0.31$ & -39.8 & -42.0 & $-7.6 \cdot 10^{-3}$ \\
\hline
\end{tabular}

The results of electrophoretic measurements conducted for the systems MLV + native or fibrillar serum albumin also are suggestive of the multilayer protein adsorption. The native albumin at the lower of the examined concentrations, $0.5 \mu \mathrm{M}$, caused the reversal of the vesicle charge (Fig. 3c). Although the net charge of bovine serum albumin is negative, $c a$. $-18 e$ at physiological $\mathrm{pH}$, the protein surface is abundant of positively charged residues that may form clusters, as illustrated in Fig. 4. At the same time, at the higher protein concentration, $2.5 \mu \mathrm{M}$, the liposomes again become negatively charged, probably because of the existence of more than one layers of the adsorbed protein. The fibrillar albumin brought about the reversal of the vesicle charge, with the absence of significant difference between the protein concentrations $0.5 \mu \mathrm{M}$ and $2.5 \mu \mathrm{M}$.

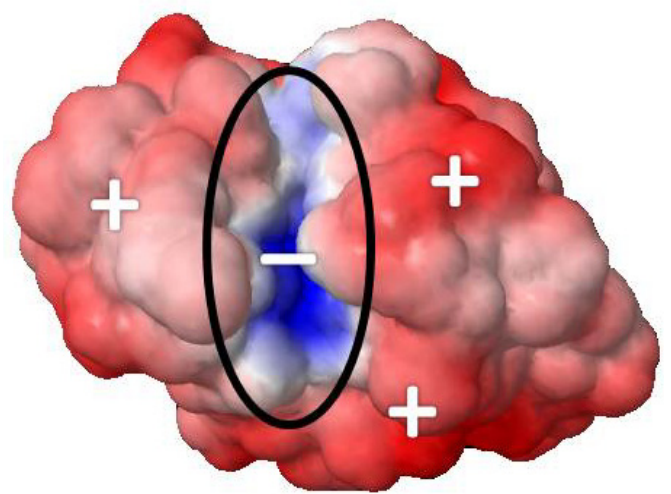

a

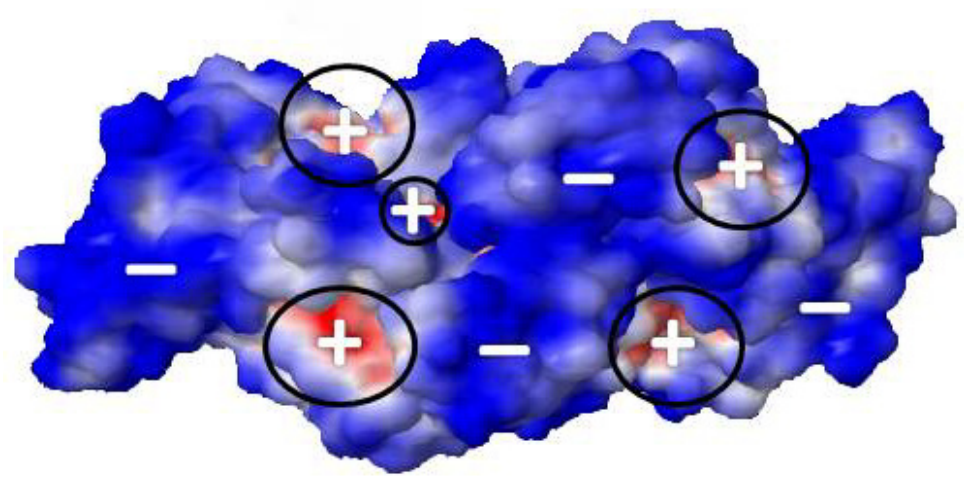

b

Fig. 4. Surface potential of the proteins

a - hen egg white lysozyme, PDB ID - 5b1f, b - bovine serum albumin, PDB ID - 4f5s.

Clusters of negatively charged lysozyme residues and positively charged albumin residues are highlighted in the figure. The values of the electrostatic surface potential varied from $-0.13 \mathrm{~V}$ to $0.13 \mathrm{~V}$. The negative and positive values of the surface potential are marked by "-" and "+", respectively. Protein structures have been prepared using the online available PDB2PQR Server, followed by the calculations of the surface potential performed in the Adaptive Poisson-Boltzmann Solver (APBS) software package

(http://www.poissonboltzmann.org/) 
In contrast to MLV, the dependence of the electrophoretic mobility and corresponding $\zeta$ - potential of LUV on the protein concentration was predominantly monotonous, with the $u$ value being gradually decreased with increasing the amount of the adsorbed protein.

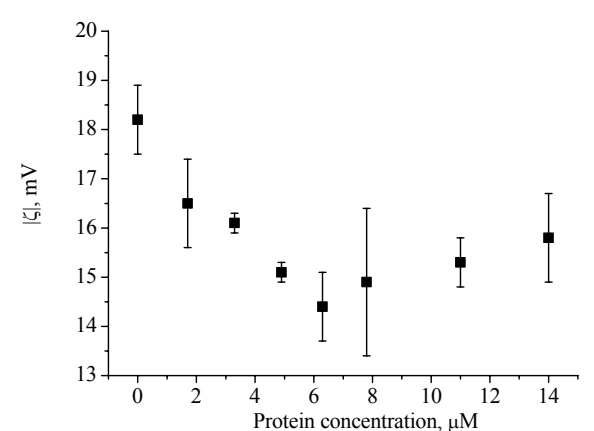

$\mathrm{a}$

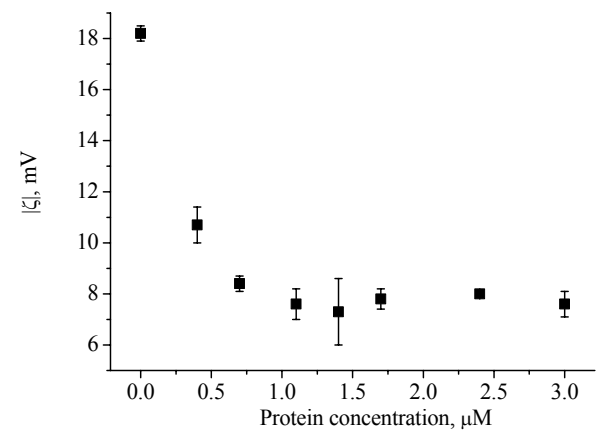

c

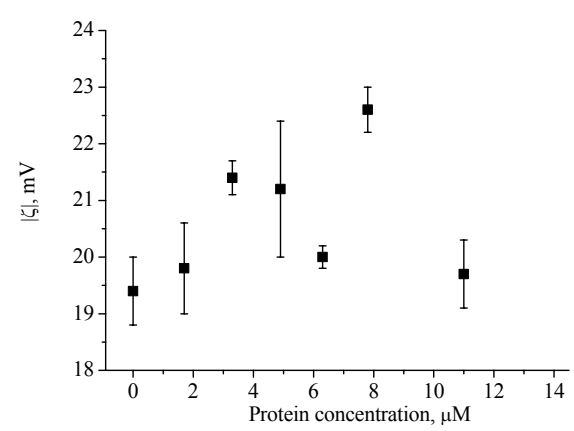

$\mathrm{b}$

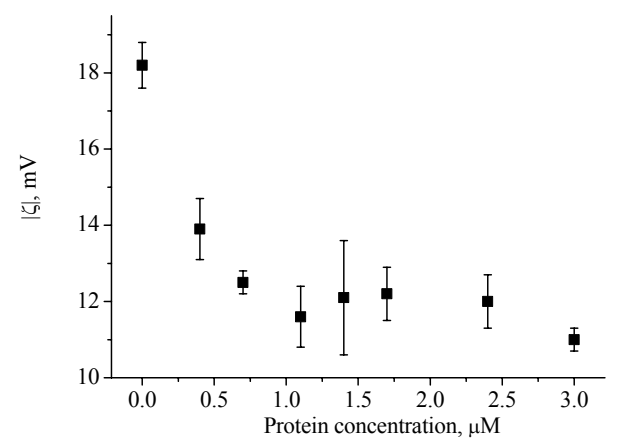

d

Fig. 5. Dependence of $|\zeta|$-potential of $\mathrm{LUV}_{\mathrm{CL} 20}$ on the concentration a - fibrillar lysozyme; $\mathrm{b}$ - native lysozyme; c - fibrillar serum albumin; $\mathrm{d}$ - native serum albumin Lipid concentration was $125 \mu \mathrm{M}$

This is not surprising since at the same total lipid concentration the vesicle surface area accessible for the protein binding is substantially higher in the suspension of unilamellar liposomes. The only exception was the case of native lysozyme, when the $\zeta$ - potential showed even the slight increase of its negative value (Fig. 5b). Under the employed experimental conditions $L_{\text {out }} / P$ ratio ranges from $\sim 37$ till $\sim 6$. If there exists only a single layer of the adsorbed protein, as is supposed for all LUV systems, it cannot be excluded that the binding of the native lysozyme to liposome surface is rather strong to achieve nearly complete covering of the membrane surface even at the lowest protein concentration. Despite the total positive charge of lysozyme, the protein bears the clusters of negatively charged residues (Fig. 4) which may impart an additional negative charge to liposome surface.

Table 2.

Electrokinetic properties of the unilamellar PC/CL (4:1, mol:mol) vesicles in the presence of native or fibrillar lysozyme and serum albumin

\begin{tabular}{|l|c|c|c|c|c|c|}
\hline Protein & $\begin{array}{c}\text { Lipid } \\
\text { concentration, } \\
\mu \mathrm{M}\end{array}$ & $\begin{array}{c}\text { Protein } \\
\text { concentration, } \\
\mu \mathrm{M}\end{array}$ & $\begin{array}{c}u, \\
\mu \mathrm{m} \cdot \mathrm{cm} / \mathrm{s} \cdot \mathrm{V}\end{array}$ & $\zeta, \mathrm{mV}$ & $\begin{array}{l}\psi_{s}, \\
\mathrm{mV}\end{array}$ & $\sigma, \mathrm{C} / \mathrm{m}^{2}$ \\
\hline \multirow{3}{*}{$\begin{array}{l}\text { Fibrillar } \\
\text { lysozyme }\end{array}$} & 125 & 0 & -1.29 & $-18.2 \pm 0.7$ & -19.2 & $-3.0 \cdot 10^{-3}$ \\
\cline { 3 - 7 } & & 1.7 & -1.17 & $-16.5 \pm 0.9$ & -17.3 & $-2.7 \cdot 10^{-3}$ \\
\cline { 3 - 7 } & & 3.3 & -1.14 & $-16.1 \pm 0.2$ & -16.9 & $-2.7 \cdot 10^{-3}$ \\
\cline { 3 - 7 } & & 4.9 & -1.07 & $-15.1 \pm 0.2$ & -15.8 & $-2.5 \cdot 10^{-3}$ \\
\cline { 3 - 7 } & & 6.3 & -1.02 & $-14.4 \pm 0.7$ & -15.1 & $-2.4 \cdot 10^{-3}$ \\
\cline { 3 - 7 } & & 7.8 & -1.05 & $-14.9 \pm 1.5$ & -15.6 & $-2.5 \cdot 10^{-3}$ \\
\cline { 3 - 7 } & & 11.0 & -1.08 & $-15.3 \pm 0.5$ & -16.0 & $-2.5 \cdot 10^{-3}$ \\
\cline { 3 - 7 } & & 14.0 & -1.12 & $-15.8 \pm 0.9$ & -16.6 & $-2.6 \cdot 10^{-3}$ \\
\hline \multirow{2}{*}{$\begin{array}{l}\text { Native } \\
\text { lysozyme }\end{array}$} & \multirow{2}{*}{125} & 0 & -1.37 & $-19.4 \pm 0.6$ & -20.4 & $-3.2 \cdot 10^{-3}$ \\
\cline { 3 - 7 } & & 1.7 & -1.4 & $-19.8 \pm 0.8$ & -20.8 & $-3.3 \cdot 10^{-3}$ \\
\hline
\end{tabular}




\begin{tabular}{|c|c|c|c|c|c|c|}
\hline Protein & $\begin{array}{c}\text { Lipid } \\
\text { concentration, } \\
\mu \mathrm{M} \\
\end{array}$ & $\begin{array}{c}\text { Protein } \\
\text { concentration, } \\
\mu \mathrm{M} \\
\end{array}$ & $\begin{array}{c}u, \\
\mu \mathrm{m} \cdot \mathrm{cm} / \mathrm{s} \cdot \mathrm{V}\end{array}$ & $\zeta, \mathrm{mV}$ & $\begin{array}{l}\psi_{s} \\
\mathrm{mV}\end{array}$ & $\sigma, \mathrm{C} / \mathrm{m}^{2}$ \\
\hline & & 3.3 & -1.51 & $-21.4 \pm 0.3$ & -22.5 & $-3.6 \cdot 10^{-3}$ \\
\hline & & 4.9 & -1.5 & $-21.2 \pm 1.2$ & -22.3 & $-3.5 \cdot 10^{-3}$ \\
\hline & & 6.3 & -1.41 & $-20.0 \pm 0.2$ & -21.0 & $-3.3 \cdot 10^{-3}$ \\
\hline & & 7.8 & -1.6 & $-22.6 \pm 0.4$ & -23.7 & $-3.8 \cdot 10^{-3}$ \\
\hline & & 11.0 & -1.39 & $-19.7 \pm 0.6$ & -20.7 & $-3.3 \cdot 10^{-3}$ \\
\hline \multirow{8}{*}{$\begin{array}{l}\text { Fibrillar } \\
\text { serum } \\
\text { albumin }\end{array}$} & \multirow[t]{8}{*}{125} & 0 & -1.29 & $-18.2 \pm 0.3$ & -19.2 & $-3.0 \cdot 10^{-3}$ \\
\hline & & 0.4 & -0.76 & $-10.7 \pm 0.7$ & -11.3 & $-1.8 \cdot 10^{-3}$ \\
\hline & & 0.7 & -0.59 & $-8.4 \pm 0.3$ & -8.8 & $-1.4 \cdot 10^{-3}$ \\
\hline & & 1.1 & -0.54 & $-7.6 \pm 0.6$ & -8.0 & $-1.2 \cdot 10^{-3}$ \\
\hline & & 1.4 & -0.52 & $-7.3 \pm 1.3$ & -7.7 & $-1.2 \cdot 10^{-3}$ \\
\hline & & 1.7 & -0.55 & $-7.8 \pm 0.4$ & -8.2 & $-1.3 \cdot 10^{-3}$ \\
\hline & & 2.4 & -0.57 & $-8.0 \pm 0.1$ & -8.4 & $-1.3 \cdot 10^{-3}$ \\
\hline & & 3.0 & -0.54 & $-7.6 \pm 0.5$ & -8.0 & $-1.2 \cdot 10^{-3}$ \\
\hline \multirow{8}{*}{$\begin{array}{l}\text { Native } \\
\text { serum } \\
\text { albumin }\end{array}$} & \multirow[t]{8}{*}{125} & 0 & -1.29 & $-18.2 \pm 0.6$ & -19.2 & $-3.0 \cdot 10^{-3}$ \\
\hline & & 0.4 & -0.98 & $-13.9 \pm 0.8$ & -14.6 & $-2.3 \cdot 10^{-3}$ \\
\hline & & 0.7 & -0.88 & $-12.5 \pm 0.3$ & -13.1 & $-2.1 \cdot 10^{-3}$ \\
\hline & & 1.1 & -0.82 & $-11.6 \pm 0.8$ & -12.2 & $-1.9 \cdot 10^{-3}$ \\
\hline & & 1.4 & -0.85 & $-12.1 \pm 1.5$ & -12.7 & $-2.0 \cdot 10^{-3}$ \\
\hline & & 1.7 & -0.86 & $-12.2 \pm 0.7$ & -12.8 & $-2.0 \cdot 10^{-3}$ \\
\hline & & 2.4 & -0.85 & $-12.0 \pm 0.7$ & -12.6 & $-2.0 \cdot 10^{-3}$ \\
\hline & & 3.0 & -0.78 & $-11.0 \pm 0.3$ & -11.6 & $-1.8 \cdot 10^{-3}$ \\
\hline
\end{tabular}

Based on the measured values of electrophoretic mobility and $\zeta$ - potentials of MLV $_{\text {CL20 }}$ and LUV CL20, we calculated the surface potential and surface charge density of liposomes assuming that the plane of shear lies at the distance $0.2 \mathrm{~nm}$ from the vesicle surface. The distance dependence of electrostatic potential is given by [28]:

$$
\psi(x)=\frac{2 k_{B} T}{e} \ln \left[\frac{1+\beta \exp (-\kappa x)}{1-\beta \exp (-\kappa x)}\right], \quad \quad \beta=\frac{\exp \left(e \psi(0) / 2 k_{B} T\right)-1}{\exp \left(e \psi(0) / 2 k_{B} T\right)+1},
$$

here $\psi(0)=\psi_{s}$. It appeared that $\psi_{s}$ values determined from the experimental data for both uni- and multilamellar liposomes are much less than the theoretical $\psi_{s}$ value predicted by the Gouy-Chapman theory $(-153 \mathrm{mV})$. This may be explained by the aforementioned effects of relaxation and retardation which reduce the rate of electromigration along with other phenomena specific for soft particles like lipid vesicles [41], and render the classical double layer theory not strictly applicable for the examined systems.

\section{CONCLUSIONS}

- The effect of the native or fibrillar lysozyme and serum albumin on the electrokinetic properties of negatively charged uni- and multilamellar liposomes from the zwitterionic lipid phosphatidylcholine and anionic lipid cardiolipin has been studied using the microelectrophoresis technique. In terms of the double layer theory the parameters, such as the $\zeta$ - potential, the surface electrostatic potential and surface charge density of the lipid vesicles have been determined upon varying the lipid-to-protein molar ratio.

- The nonmonotonous dependence of the electrokinetic parameters on the protein concentration and reversal of the liposome charge observed for the multilamellar lipid vesicles have been interpreted as a manifestation of multilayer protein adsorption on the liposomal surface.

- The predominant tendency in the electrokinetic behavior of unilamellar liposomes lies in the gradual decrease of the $\zeta$ - potential with increasing the protein concentration, suggesting the existence of a single layer of the adsorbed protein.

- The revealed differences in the effect of the native and fibrillar protein forms on the charge of liposomal membranes point to the distinct lipid-associating abilities of the monomeric and aggregated proteins.

\section{REFERENCES}

1. Cevc G. Membrane electrostatics // Biochim. Biophys. Acta. - 1990. - Vol. 1031. - P. 311-382.

2. Demchenko A.P., Yesylevskyy S.O. Nanoscopic description of biomembrane electrostatics: results of molecular dynamics simulations and fluorescence probing // Chem. Phys. Lipids. - 2009. - Vol. 169. - P. 63-84.

3. Cho W.H., Stahelin R.V. Membrane-protein interactions in cell signaling and membrane trafficking // Annu. Rev. Biophys. Biomol. Struct. - 2005. - Vol. 34. - P. 119-151. 
4. Murray D., Arbuzova A., Honig B., McLaughlin S. The role of electrostatic and nonpolar interactions in the association of peripheral proteins with membranes // Pept. Lipid Interact. - 2002. - Vol. 52. - P. 277-307.

5. Mulgrew-Nesbitt A., Diraviyam K., Wang J.Y., Singh S., Murray P., Li Z.H., L. Rogers, Mirkovic N., Murray D. The role of electrostatics in protein-membrane interactions // Biochim. Biophys. Acta. - 2006. - Vol. 1761. - P. 812-826.

6. Bazzi M.D., Nelsestuen G.L. Association of protein kinase C with phospholipid vesicles // Biochemistry. - 1987. - Vol. 26 P.115-122.

7. Newton A.C., Koshland D.E. Regulation of protein kinase C activity by lipid // Biophys. J. - 1989. - Vol. 55. - P. 209a.

8. Smejtek P., Wang S.R. Adsorption to dipalmitoylphosphatidylcholine membranes in gel and fluid state: pentachlorophenolate, dipicrylamine, and tetraphenylborate // Biophys. J. - 1990. - Vol. 58. - P. 1285-1294.

9. Gennis R.B. Biomembranes: Molecular Structure and Function. - New York: Springer-Verlag, 1989.

10. Anderluh G., Lakey J.H. Disparate proteins use similar architectures to damage membranes // Trends Biochem. Sci. - 2008. Vol. 33. - P. 482-490.

11. Ben-Tal N., Honig B., Miller C., McLaughlin S. Electrostatic binding of proteins to membranes. Theoretical predictions and experimental results with charybdotoxin and phospholipid vesicles // Biophys. J. - 1997. - Vol. 73. - P. 1717-1727.

12. Zschornig O., Opitz F., Muller M. Annexin A4 binding to anionic phospholipid vesicles modulated by $\mathrm{pH}$ and calcium // Eur. Biophys. J. - 2007. - Vol. 36. - P. 415-424.

13. Kurganov B., Doh M., Arispe N. Aggregation of liposomes induced by the toxic peptides Alzheimer's A beta s, human amylin and prion (106-126): facilitation by membrane-bound G(M1) ganglioside // Peptides. - 2004. - Vol. 25. - P. $217-232$.

14. Cho W.J., Jena B.P., Jeremic A.M. Nano-scale imaging and dynamics of amylinmembrane interactions and its implication in type II diabetes mellitus // Methods Cell Biol. - 2008. - Vol. 90. - P. 267-286.

15. Davidson W.S., Jonas A., Clayton D.F., George J.M. Stabilization of alpha-synuclein secondary structure upon binding to synthetic membranes // J. Biol. Chem. - 1998. - Vol. 273. - P. 9443-9449.

16. Elbaum-Garfinkle S., Ramlall T., Rhoades E. The role of the lipid bilayer in tau aggregation // Biophys. J. - 2010. - Vol. 98. P. 2722-2730.

17. Trexler A.J., Rhoades E. Alpha-synuclein binds large unilamellar vesicles as an extended helix // Biochemistry. - 2009. - Vol. 48. - P. 2304-2306.

18. Stefani M. Protein misfolding and aggregation: new examples in medicine and biology of the dark side of the protein world // Biochim. Biophys. Acta. - 2004. - Vol. 1739. - P. 5-25.

19. Zerovnik E. Amyloid-fibril formation. Proposed mechanisms and relevance to conformational disease // Eur. J. Biochem. 2002. - Vol. 269. - P. 3362-3371.

20. Stefani M. Generic cell dysfunction in neurodegenerative disorders: role of surfaces in early protein misfolding, aggregation, and aggregate cytotoxicity // Neuroscientist. - 2007. - Vol. 13. - P. 519-531.

21. Meratan A.A., Ghasemi A., Nemat-Gorgani M. Membrane integrity and amyloid cytotoxicity: a model study involving mitochondria and lysozyme fibrillation products // J. Mol. Biol. - 2011. - Vol. 409. - P. 826-838.

22. Caughey B., Lansbury P.T., Protofibrils, pores, fibrils, and neurodegeneration: separating the responsible protein aggregates from the innocent bystanders // Annu. Rev. Neurosci. - 2003. - Vol. 26. - P. 267-298.

23. Sparr E., Engel M.F.M., Sakharov D.V., Sprong M., Jacobs J., de Kruijf B., Hoppener J., Killian J.A. Islet amyloid polypeptideinduced membrane leakage involves uptake of lipids by forming amyloid fibers // FEBS Lett. - 2004. - Vol. 577. - P. 117-120.

24. Arispe N., Rojas E., Pollard H. Alzheimer's disease amyloid beta protein forms calcium channels in bilayer membranes: blockade by tromethamine and aluminium // Proc. Natl. Acad. Sci. U.S.A. - 2003. - Vol. 89. - P. 10940-10944.

25. Pepys M.B., Hawkins P.N., Booth D.R., Vigushin D.M., Tennent G.A., Souter A.K., Totty N., Nguyen O., Blake C.C., Terry C.J., Feest T.G., Zalin A.M., Hsuan J.J. Human lysozyme gene mutations cause hereditary systemic amyloidosis // Nature. - 1993. - Vol. 362. - P. 553-557.

26. Sen P., Fatima S., Ahmad B., Khan R.H. Interactions of thioflavin T with serum albumins: Spectroscopic analyses // Spectrochimica Acta Part A. - 2009. - Vol. 74. - P. 94-99.

27. Arasteh A., Habibi-Rezaei M., Ebrahim-Habibi A., Moosavi-Movahedi A.A. Response surface methodology for optimizing the bovine serum albumin fibrillation // Protein J. - 2012. - Vol. 31. - P. 457-465.

28. McLaughlin S. The electrostatic properties of membranes // Annu. Rev. Biophys. Biophys. Chem. - 1989. - Vol. 18. - P. 113136.

29. Jahnig F. Electrostatic free energy and shift of the phase transition for charged lipid membranes // Biophys. Chem. - 1976. Vol. 4. - P. 309-318.

30. Malyshka D., Pandiscia L.A., Schwweitzer-Stenner R. Cardiolipin containing liposomes are fully ionized at physiological pH. An FT-IR study of phosphate group ionization // Vib. Spectrosc. - 2014. - Vol. 75. - P. 86-92.

31. Chan D., Horn R.G. The drainage of thin liquid films between solid surfaces // J. Chem. Phys. - 1985. - Vol. 83. - P. 53115324.

32. Israelachvili J. Measurement of the viscosity of liquids in very thin films // J. Colloid Interface Sci. - 1986. - Vol. 110. - P. 263-271.

33. Horn R.G., Smith D.T., Haller W. Surface forces and viscosity of water measured between silica sheets // Chem. Phys. Lett. 1989. - Vol. 162. - P. 404-408.

34. O'Brien R.W., Hunter R.J. The electrophoretic mobility of large colloidal particles // Can. J. Chem. - 1981. - Vol. 59. - P. 1878-1887.

35. O'Brien R.W. The solution of the electrokinetic equations for colloidal particles with thin double layer // J. Colloid Interface Sci. - 1982. - Vol. 92. - P. 204-216.

36. O’Brien R.W., Ward D.N. The electrophoresis of a spheroid with a thin double layer // J. Colloid Interface Sci. - 1988. - Vol. 121. - P. 402-413.

37. Jaffe L.F. Electrophoresis along cell membranes // Nature. - 1977. - Vol. 265. - P. 600-602.

38. Poo M., Lam J.W., Orida N., Chao A.W. Electrophoresis and diffusion in the plane of the cell membrane // Biophys. J. - 1979. 
- P. 1-21.

39. Groves J., Boxer S., McConnell H. Electric field-induced critical demixing in lipid bilayer membranes // Proc. Natl. Acad. Sci. U.S.A. - 1998. - Vol. 95. - P. 935-938.

40. Sokirko A., Pastushenko V., Svetina S., Zeks B. Deformation of a lipid vesicle in an electric field: a theoretical study // Bioelectrochem. Bioenerg. - 1994. - Vol. 34. - P. 101-107.

41. Pysher M.D., Hayes M.A. Examination of the electrophoretic behavior of liposomes // Langmuir. - 2004. - Vol. 20. - P. 43694375. 